\title{
Investigative study of the potentialities of noble applications for the Brazilian calcium sulfate $\boldsymbol{\alpha}$-hemihydrate
}

\author{
Marcela Cristine de Alencar Lira (i) \& Laédna Souto Neiva
}

Federal University of Cariri, Science and Technology Center, Materials Engineering, Avenue Tenente Raimundo Rocha 1639, Cidade Universitária 63048-080, Juazeiro do Norte, Ceará, Brazil. E-mail: marcela.alencar@aluno.ufca.edu.br, laedna.neiva@ufca.edu.br

Lira M.C.A. \& Neiva L.S. (2020) Investigative study of the potentialities of noble applications for the Brazilian calcium sulfate $\alpha$-hemihydrate. Pesquisa e Ensino em Ciências Exatas e da Natureza, 4: e1516. http://dx.doi.org/10.29215/pecen.v4i0.1516

Academic editor: Fernando Antônio Portela da Cunha. Received: 28 September 2020. Accepted: 06 October 2020. Published: 07 October 2020.

Estudo investigativo das potencialidades de aplicações nobres para o hemihidrato de sulfato de cálcio brasileiro do tipo

Resumo: O sulfato de cálcio hemiidratado (comercialmente conhecido como gesso) é obtido através da desidratação parcial do minério gipsita. A depender das condições termodinâmicas de calcinação do minério podem ser obtidas diferentes variações do hemihidrato. O objetivo deste trabalho é realizar um estudo investigativo acerca das possibilidades de aplicações nobres para o hemihidrato tipo $\alpha$. Para isto, foi analisada uma amostra do gesso $\alpha$ proveniente do estado de Pernambuco, Brasil, por meio de técnicas de caracterizações estruturais e químicas. De acordo com os resultados, a amostra apresentou composição majoritariamente a base de sulfato de cálcio associado à água, com teor de pureza igual a 98.79\%. As partículas apresentaram tamanho médio, aproximadamente uniforme, em torno de $60 \mu \mathrm{m}$. A concentração insignificante de contaminantes detectados na amostra torna o hemihidrato $\alpha$ adequado para aplicações nobres como, por exemplo, na área da saúde dentre outras aplicações que impliquem em contato literal com organismos vivos.

Palavras chave: $\alpha$-Hemihidrato de sulfato de cálcio, gesso alfa, investigação de potencialidades, caracterizações estruturais.

\begin{abstract}
Calcium sulfate hemihydrate (commercially known as gypsum or plaster) is obtained through partial dehydration of the gypsum crude ore. Depending on the thermodynamic conditions of calcination of the ore, different variations of the hemihydrate can be obtained. The aim of this work is to carry out an investigative study on the possibilities of noble applications for $\alpha$-type calcium sulfate hemihydrate. For this, a sample of $\alpha$ plaster from state of Pernambuco, in Brazil, was analyzed using structural and chemical characterization techniques. According to the results, the sample presented a composition mainly based on calcium sulfate associated with water, with a purity content equal to $98.79 \%$. The particles had an average size, approximately uniform, around $60 \mu \mathrm{m}$. The insignificant concentration of contaminants detected in the sample indicates that the $\alpha$ plaster sample analyzed can be considered suitable for noble applications such as, in the health area, among other applications that imply literal contact with living organisms.
\end{abstract}

Key words: Calcium Sulfate $\alpha$-Hemihydrate, alpha plaster, investigation of potentialities, structural characterizations.

\section{Introduction}

Gypsum or plaster is a calcium sulfate hemihydrated that has a chemical formula $\mathrm{CaSO}_{4} \cdot 0.5 \mathrm{H}_{2} \mathrm{O}$. It uses a single raw material for its production, the gypsum crude ore (calcium sulfate dihydrate - $\mathrm{CaSO}_{4} \cdot 2 \mathrm{H}_{2} \mathrm{O}$ ) (Ferreira et al. 2019). For Tritschler (2015) apud Gurgul et al. (2019), depending on the thermodynamic conditions of the calcination of the gypsum crude ore, 
the hemihydrates obtained can be presented in two main variants, namely $\alpha$ and $\beta$. Currently, there are several calcination processes for the production of comercial plaster, basically distinguishing into two categories: (1) calcination at atmospheric pressure for the production of $\beta$ type plaster and (2) calcination at high pressure to produce $\alpha$ type plaster (Soares 2005).

In general, the gypsum crude ore calcination product is a very important inorganic material for the industry, given its wide range of applications that range from civil construction, to medicine, automobile segments, cosmetics and ceramics industries (Lira 2018). Chemically and crystallographically, there are not differences between the $\alpha$ and $\beta$ types of plaster, however due to the conformation and size of the crystals the specific surface presented by $\alpha$ plaster is smaller in relation to $\beta$. The $\alpha$ type plaster acquires a consistency with less mixing water and produces parts with less porosity and superior mechanical resistance to flexion (Abreu 2005).

Calcium sulfate hemihydrate is produced in great abundance in the region of Araripe in the state of Pernambuco, northeastern Brazil, and presents degrees of purity that vary between 80 and $95 \%$. The gypsum crude ore can be present in nature under several mineralogical species, the most well-known are: Cocadinha, Estrelinha, Rapadura, Johnson among others, which vary basically between themselves in relation to the purity content (Barbosa et al. 2014).

The calcium sulfate $\alpha$-hemihydrate is widely recognized in the literature as a high valueadded cementitious material due to the ease that this material presents for molding processes in addition to presenting high mechanical strength and favorable biocompatibility (Jiang et al. 2016; Singh \& Middendorf 2007 apud Ma et al. 2018). For Kwon et al. (2016), plaster is an almost exclusive material for the development of dental models for prosthetic and orthodontic rehabilitation or for the analysis of temple and jaw joints. Following this line of applications in the health area, case studies involving the use of plaster as an inorganic material associated with special therapy techniques aimed at correcting anatomical deformities in the treatment of orthopedic injuries, such as pseudoarthrosis, can also be mentioned, for bone grafts and for making a provisional nasal prosthesis for the treatment of recovery from a geriatric oncological rhinectomy (Rosen et al. 2019; Chang et al. 2020; Chen et al. 2020; Zhao et al. 2020).

Research reports describing or ratifying the well-known antipyretic activity of gypsum crude ore, not calcined, when applied as a paste to the skin of a fevered person are not uncommon in the literature and, due to this property, this inorganic material has been widely used with satisfactory performance in the treatment of mild symptoms such as fever in people infected with the new coronavirus (Shahrajabian et al. 2020; Wang et al. 2020; Zhou et al. 2020)

Aligned with this context, the aim of this work is to perform structural and chemical characterization in $\alpha$ type sample of calcium sulfate hemihydrate, belonging to Johnson mineralogical classification, from Plasterer Polo of Araripe, located in state of Pernambuco, in Brazil. The driving motivation for carrying out this work consists of investigating, in a speculative way, the potential of noble applications or distinct from the trivial application in civil construction, for the material object of study of this research from the results of its characterizations.

\section{Material and Methods}

The $\alpha$-type sample of calcium sulfate hemihydrate, also known commercially as $\alpha$-type plaster, analyzed in this work comes from the large gypsum crude ore deposits located in the mineral reserves belonging to Chapada do Araripe. Specifically, the sample analyzed in this work comes from the reserves that are located in state of Pernambuco, in Brazil. The sample studied in this work was converted from its crude form of gypsum ore, in mineralogical variety classified as Johnson, into calcium sulfate $\alpha$-type hemihydrate by means of industrial calcination processing under water vapor pressure in autoclave oven with a temperature at $140^{\circ} \mathrm{C}$. The processing of conversion of gypsum crude ore into $\alpha$-type hemihydrate was carried out in the industrial facilities of one of the companies that make up the industrial complex known as Plasterer Polo of Araripe, which provided a sample of the material ready to be marketed. Henceforth, the sample calcium sulfate $\alpha$-type hemihydrate, which was received and analyzed in 
this work, will be called only $\alpha$ plaster. The plaster sample $\alpha$ was then prepared for characterization by sieving in a 200 \# mesh, $44 \mu \mathrm{m}$ aperture, and the sieving product was then submitted to characterizations analysis. The following is a brief summary of the characterization analyzes to which the $\alpha$ plaster sample was submitted. X-ray diffraction analysis was applied in order to identify the phases present in the sample structure of the material, in order to quantify its purity. This analysis was then performed on a Shimadzu diffractometer, model XRD 7000, which is equipped with the following parameters: copper target; $40 \mathrm{kV}$ voltage and $30 \mathrm{~mA}$ current. A characterization analysis via X-ray fluorescence - XRF - was performed in order to identify the qualitative and semi-quantitative chemical composition of the $\alpha$ plaster sample. This $\mathrm{XRF}$ analysis was performed on a dispersive energy X-ray fluorescence spectrometer, brand Shimadzu, model EDX 7000/8000. Morphological aspects of the unitary particles and their agglomerates that make up the $\alpha$ plaster sample were observed using the scanning electron microscopy technique - SEM. This analysis was performed using a scanning electron microscope from the manufacturer TESCAN and identification by veg3, operated at $20 \mathrm{kV}$. The observation of the behavior of the $\alpha$ plaster sample with regard to its mass loss capacity, under heating conditions, was performed using the characterization technique known as thermogravimetry; for this, was used a Shimadzu thermal analyzer, model TGAA-50/50H using the following parameters: dynamic air atmosphere of $50 \mathrm{~mL} \cdot \mathrm{min}^{-1}$ and heating rate of $15^{\circ} \mathrm{C} . \mathrm{min}^{-1}$.

Finally, Fourier transform infrared (FT-IR) spectra obtained in the range between 450 and $4000 \mathrm{~cm}-1$, in the transmittance mode, were plotted using $\mathrm{KBr}$ pellets as a reference in a Perkin Elmer Spectrum Two spectrophotometer. This analysis aims to ratify, corroborate or detail information collected in previous analyzes of structural characterizations such as x-ray diffraction and x-ray fluorescence.

\section{Results and Discussion}

\section{X-ray Diffraction}

Figure 1 depicts the $\alpha$ plaster analyzed sample XRD patterns. This analysis was carried out in order to identify and quantify the constituent phases of the sample structure studied in this work. From the data collected in this analysis, the phases identification was performed using Malvern Panalytical's X'Pert HighScore Plus Software and the ICDD database (International Centre for Diffraction Data).

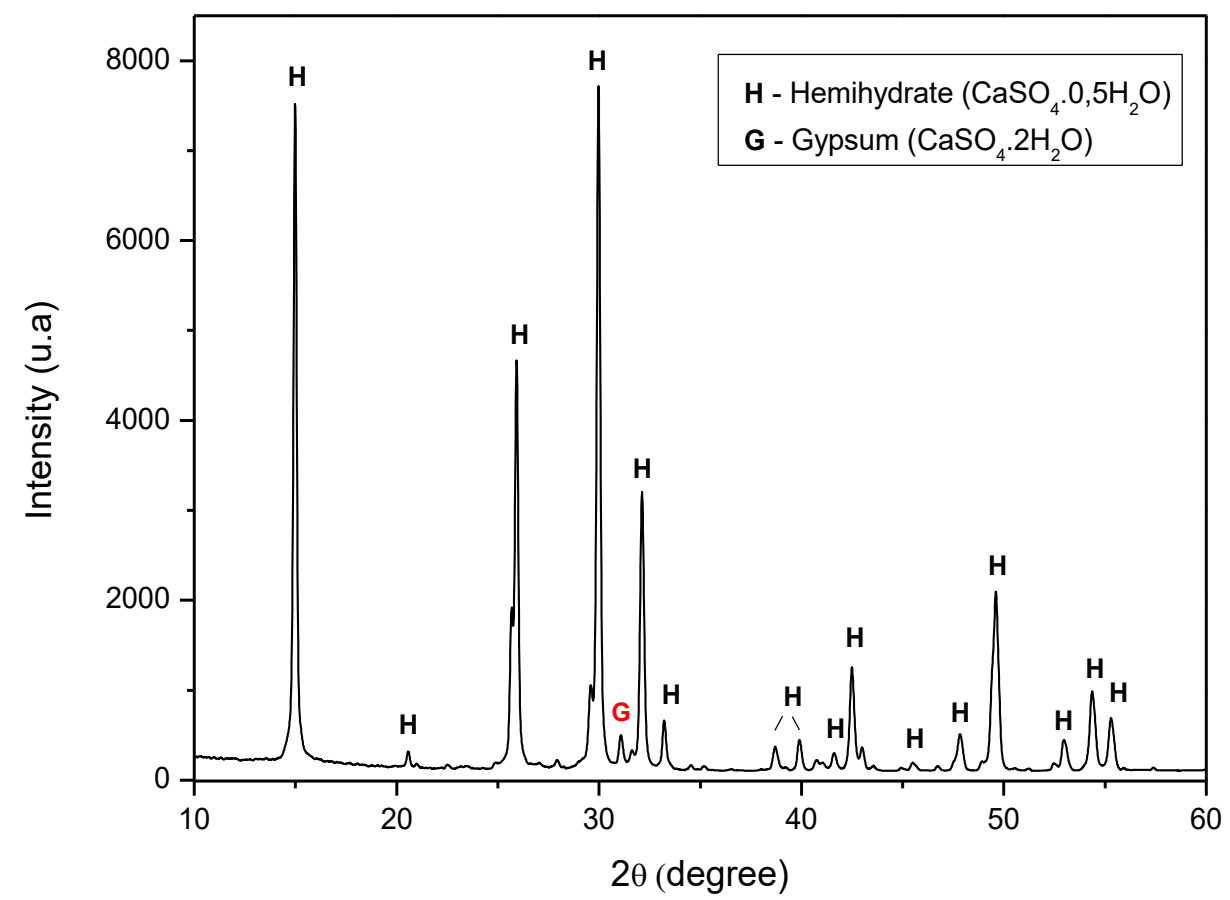

Figure 1. X-ray diffraction patterns for $\alpha$ plaster analyzed sample. 
When observing at the x-ray patterns, depicts by Figure 1, the pronounced degree of purity of the $\alpha$ plaster sample is evident; i.e., the graphical profile of the $\mathrm{x}$-ray patterns shows that the sample in question is essentially composed on Calcium Sulfate Hemihydrate (Card ICDD 00-033-0310), because only the high intensity peaks characteristic of that $(\mathrm{H})$ phase were identified $\left(\mathrm{CaSO}_{4} \cdot 0.5 \mathrm{H}_{2} \mathrm{O}\right)$. The high intensity peaks characteristic of the phase already mentioned, were detected at $2 \theta=14.75^{\circ}, 25.65^{\circ}$ and $29.69^{\circ}$ associated respectively to (l $\left.\begin{array}{lll}1 & 0 & 1\end{array}\right),\left(\begin{array}{lll}3 & 0 & 1\end{array}\right)$ and $\left(\begin{array}{lll}4 & 0 & 0\end{array}\right)$ crystallographic planes. It is also possible to observe the brief occurrence of a low intensity peak at $2 \theta=31.121^{\circ}$, referring to the gypsum phase (G) (Card ICDD 00-021-0816), this being associated with the (2 00 ) crystallographic plane. According to Oliveira \& Torres (2015), the appearance of the characteristic peak of gypsum can be associated with two factors: (i) deficiency in calcination or (ii) hydration in storage.

In addition to the non-detection of spurious phases in the crystalline structure of the $\alpha$ plaster sample the high purity of this sample was ratified by the absence of the anhydrite phase, or anhydrous calcium sulfate $-\mathrm{CaSO}_{4}$, since this phase is the most common contaminant found in calcination products of the gypsum crude ore to obtain plaster, according to Baltar et al. (2008).

\section{X-Ray Fluorescence}

The result of the analysis of the qualitative and semi-quantitative chemical composition, performed using XRF technique, for the $\alpha$ plaster sample, is describes below in Table 1 .

According to describes data in Table 1, it appears that the composition of the $\alpha$ plaster sample is constituted by expressive levels of calcium oxide $(\mathrm{CaO})$ and sulfuric anhydrous $\left(\mathrm{SO}_{3}\right)$, totaling $98.79 \%$ of the total composition. Despite the detection of the presence of contaminating oxides in the sample, it is possible to observe that, in general, the concentration of these contaminants is very low, limited to a total of $1.2 \%$. The insignificant content of the concentration of each contaminating oxide, individually, may justify the fact that themselves were not detected in XRD analysis.

Table 1. Chemical composition obtained by X-ray fluorescence for the $\alpha$ plaster sample.

\begin{tabular}{c|ccccccc}
\hline Analyte & $\mathrm{CaO}$ & $\mathrm{SO}_{3}$ & $\mathrm{Al}_{2} \mathrm{O}_{3}$ & $\mathrm{SiO}_{2}$ & $\mathrm{SrO}$ & $\mathrm{Fe}_{2} \mathrm{O}_{3}$ & $\mathrm{TiO}_{2}$ \\
\hline Content (wt \%) & 54.109 & 44.687 & 0.473 & 0.458 & 0.175 & 0.084 & 0.014 \\
\hline
\end{tabular}

The most classic or trivial application for plaster is in the construction industry, where a material with an expressive purity content is not strictly required as discussed in the research work carried out by Marvila et al. (2020), where the feasibility of using a plaster coating was analyzed, in historic buildings in a city of the state of Rio de Janeiro, containing residues of differents rock materials as a way of reducing the accumulation of solid urban waste. Another example of successful application in civil construction, which also does not require composition with an expressive degree of purity, is the case of the work developed by Buggakupta et al. (2020) which employed waste from automotive glass shards and plaster mold hulls used in steel industries as inputs for the manufacture of plaster-based mortars. The result of this research was very positive from an environmental point of view as well as technical and economic feasibility. However, the high purity content of the $\alpha$ plaster sample, object of study of this work, adds a lot of value to this material and makes it very attractive for noble applications such as in the health area, among other applications that directly imply a literal contact with living organisms, for which non-toxic materials are usually required. Therefore, it is worth mentioning that the expressive purity content of the $\alpha$ plaster sample analyzed in this work proved to be superior when compared with the $\alpha$-type hemihydrate sample successfully synthesized by a group of Vietnamese researchers from of calcium sulfate dihydrate crude ore calcined under high pressure. In this work taken as reference, the $\alpha$-type hemihydrated sample obtained proved with $98.62 \%$ purity degree and in the research in question, the same sample was submitted to 
biocompatibility tests for application in bone graft. As conclusion, the referenced research found that the analyzed $\alpha$-type hemihydrate sample can be considered a promising substitute for the synthetic materials currently used for bone grafts in orthopedic and maxillofacial surgeries (Ngoc Le et al. 2020).

\section{Scanning Electron Microscopy (SEM)}

The micrographs obtained as result of the morphological analysis, performed by scanning electron microscopy (SEM) technique, in the analyzed $\alpha$ plaster sample, in powder form, are illustrated in Figure 2 with 500x and 2000x magnification.

From the observation of the micrographs, it is possible to see that the $\alpha$ plaster sample is formed by a cluster of unitary particles joined most likely by low intensity bonding forces, probably of the Van der Walls type, given the easily of de-agglomeration of this material, analyzed in powder form. The morphological aspect of the unitary particles and their agglomerates that make up the sample, shown in the micrographs, are mostly presented with an elongated, fine physical shape and with approximately uniform lengths, around $60 \mu \mathrm{m}$ (Figure 2A). Figure 2B, in which the $\alpha$ plaster sample image is displayed with greater magnification, it is possible to notice that the unitary particles as well as their agglomerates present with irregular and inhomogeneous surface aspects.

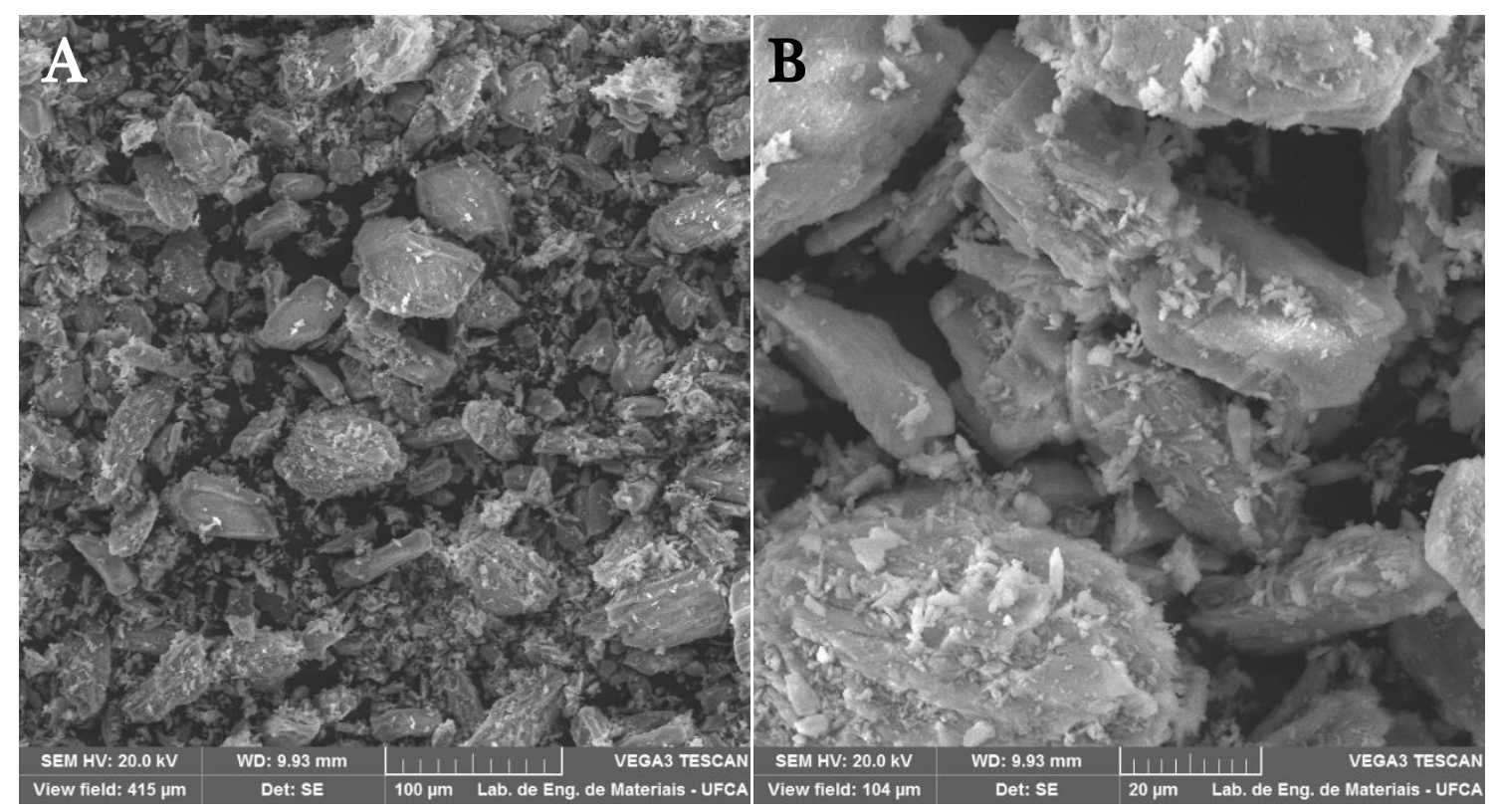

Figure 2. SEM micrographs of the morphology of analyzed $\alpha$ plaster sample in powder form: A. 500x magnification; B. 2000x magnification.

Interestingly, in a research conducted by Guan et al. (2020) that investigated the mechanical properties of gypsum-based composite materials concluded that when particles or gypsum crystals have physical characteristics with elongated and thin shapes or even stick shapes, this morphological characteristic tends to promote the formation of shear stresses inside the material structure, thus increasing its mechanical resistance, when compared to other particle morphologies also addressed in the same work. Thus, this type of particle or plaster crystal morphology can be very interesting for applications that require this type of improvement.

\section{Thermogravimetric Analysis (TGA)}

The graphic profiles representative of the curves for mass loss, obtained via thermogravimetric analysis (TGA) as well as its first derivative (DTGA) for the $\alpha$ plaster sample are presented in Figure 3. 


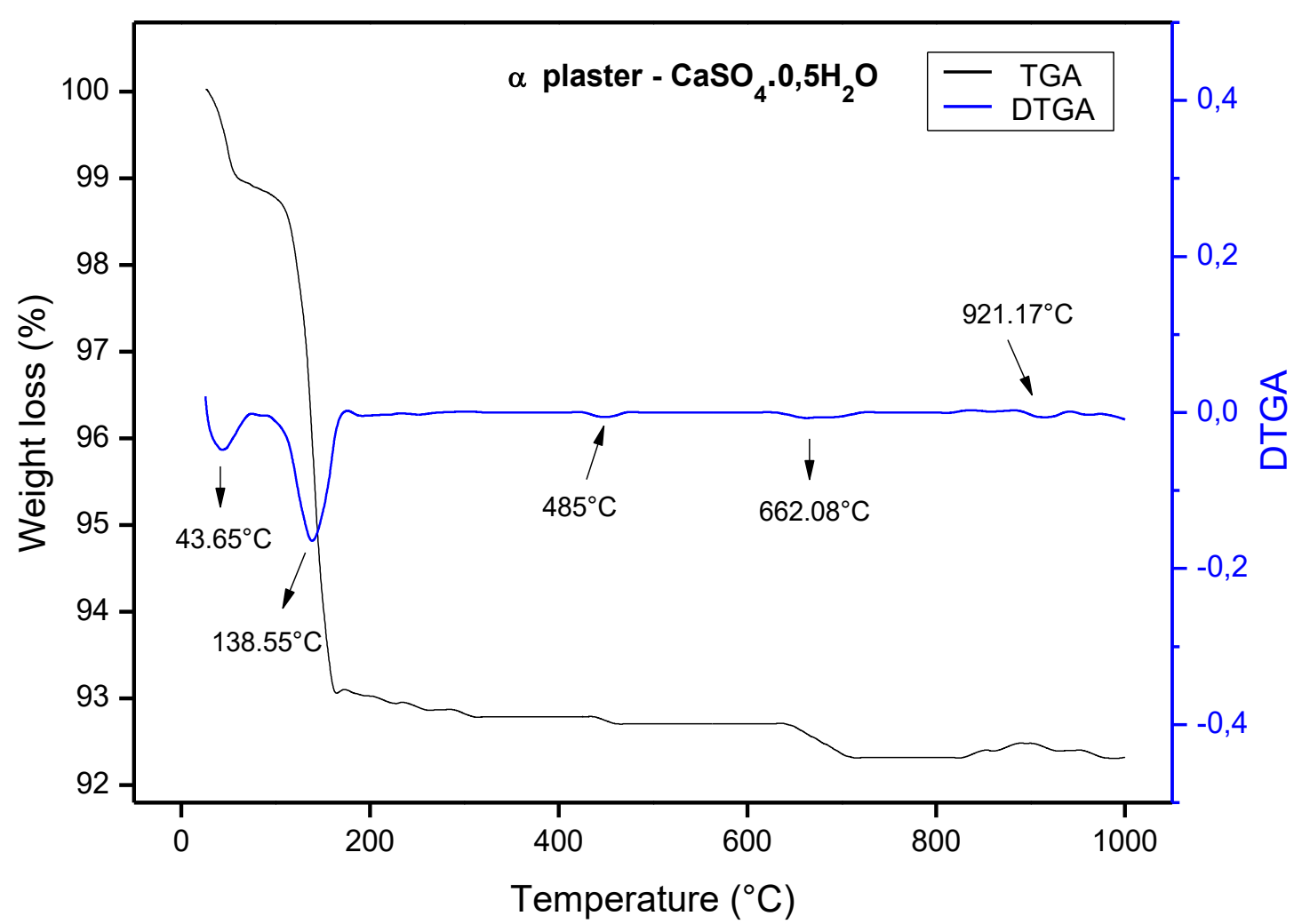

Figure 3. Graphic profiles representative of the data from the thermogravimetric analysis (TGA/DTGA) for $\alpha$ plaster sample, in dynamic air atmosphere, $50 \mathrm{~mL} \cdot \mathrm{min}^{-1}$.

When analyzing the thermogravimetric profile of the $\alpha$ plaster sample it was possible to notice the presence of three main peaks representative of mass loss occurrences. According to the graph, the first occurrence of mass loss occurred under the maximum temperature value of $43.65^{\circ} \mathrm{C}$, probably related to a loss of free water still existing in the sample. The second mass loss event, occurred with a maximum of $138.55^{\circ} \mathrm{C}$, most likely related to the loss of part of the crystallization water, these values detected in this analysis referring to the temperatures of partial dehydration of the gypsum with its consequent conversion to the form hemihydrate are in accordance with research reports related to the investigation of this type of ore published in the literature (Krause et al. 2020; Ritterbach \& Becker 2020). Some discrete events were perceived at temperatures above $450^{\circ} \mathrm{C}$ suggesting the presence of thermally active components, which were not detected by XRD analysis. Comparing this graphic construction based on the data from the TGA/DTGA analysis with the results of the XRF analysis, it is plausible to deduce that these little pronounced events may be related with thermal decompositions of the contaminating oxides detected in the chemical composition which has been described in Table 1 for the $\alpha$ plaster sample. Engbrecht \& Hirschfeld (2016) carried out an investigative research on the thermal behavior of calcium sulfate dihydrate and in their studies it was proven that the gypsum sample investigated underwent thermal decomposition of carbonate components (calcite and dolomite) at temperature close to $700^{\circ} \mathrm{C}$, which had not been revealed in the XRD analysis. Another plausible hypothesis to justify the discrete events observed in the graph shown in Figure 3 may be related to the evaporation of the remaining water in the crystalline structure of the $\alpha$ plaster sample, object of study of this work, with the probable formation of anhydrite. It is not uncommon to find references in the literature that point to the formation of anhydrous calcium sulphate related to the complete dehydration of calcium sulphate hemihydrate (Canut 2003 apud Canut 2006; Costa 2013; Marandi et al. 2017).

Fourier Transform Infrared Spectroscopy (FT-IR) 
Figure 4 shows the FTIR spectra for the analyzed $\alpha$ plaster sample in this work. The information presented by result of the FTIR analysis endorses the high purity of the $\alpha$ plaster sample, corroborating the results of the XRD and FRX analysis already discussed.

According to the FTIR graphic spectra, shown in Figure 4, the composition of the $\alpha$ plaster sample analyzed in this work is essentially composed by calcium sulfate in humidity presence. Furthermore, no peak or band occurrence was detected, alluding to the presence of compounds other different those already identified in previous structural and chemical characterizations. Analyzing this FTIR spectra, it was found that the peaks that were located between the range of 3067 and $3490 \mathrm{~cm}^{-1}$ are according to reports published in the literature, attributed to the bond length of the functional group $\mathrm{OH}$, an indication of the humidity presence in the sample. The peak identified exactly at $1619 \mathrm{~cm}^{-1}$ alludes to the flexion vibrations of water molecules present in the sample. Finally, it was found that the peaks located in the wave range between 1100 and $590 \mathrm{~cm}^{-1}$ are attributed to the asymmetric vibrations of the bonds of the sulfate group - $\mathrm{SO}_{4}{ }^{2-}$ (Huynh et al. 2020; Li \& Zhang 2020; Maale et al. 2020; Zhang et al. 2020).

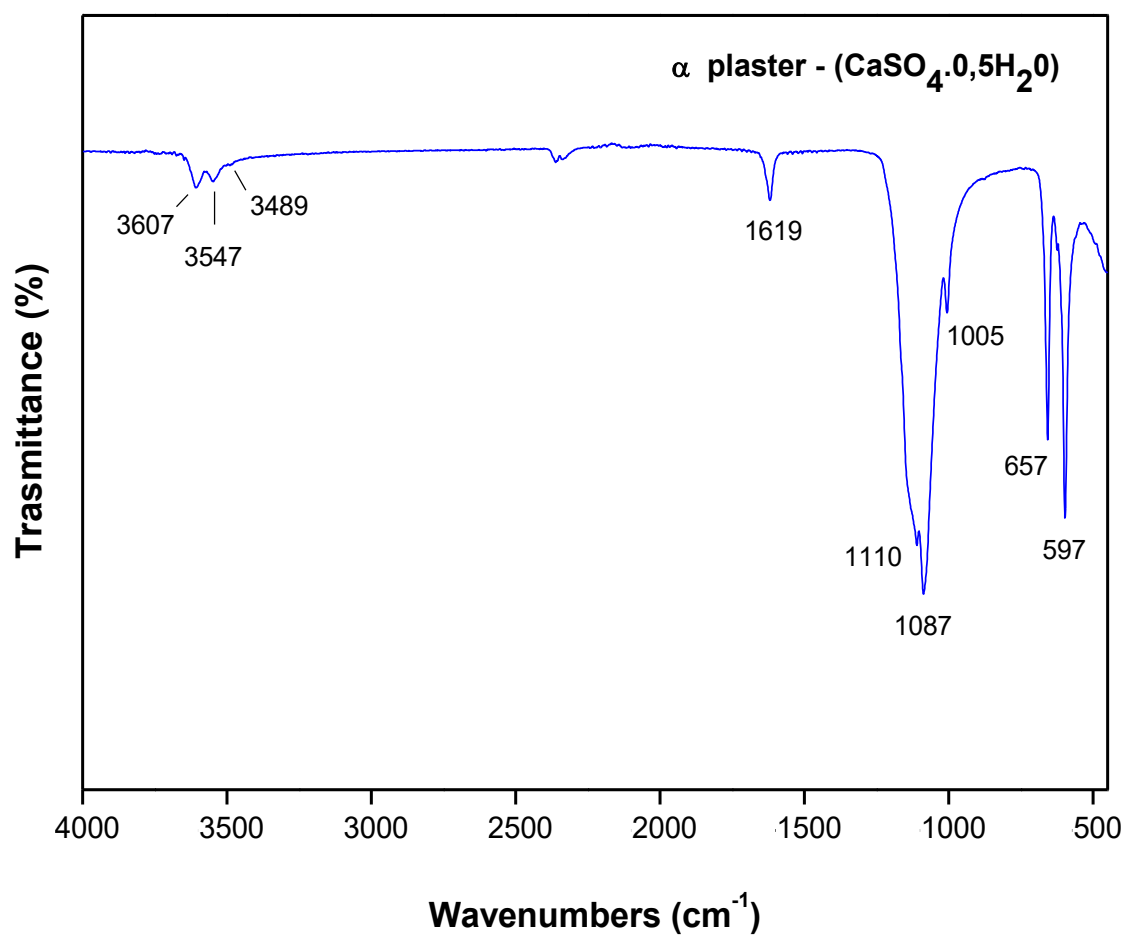

Figure 4. Fourier Transform Infrared (FTIR) spectra for the $\alpha$ plaster sample.

\section{Conclusions}

The sample of Brazilian gypsum, from state of Pernambuco, analyzed in this work, belonging to the mineralogical variety Johnson and called $\alpha$ plaster, presented mineralogical composition mostly based on calcium sulfate hemihydrate, $\alpha-\mathrm{CaSO}_{4} \cdot 0.5 \mathrm{H}_{2} \mathrm{O}$, with a content of purity around $98.79 \%$; thus, the sample of the $\alpha$ plaster analyzed was shown to be suitable for applications that require minimal possibilities of toxicity, such as, applications in the health area, among others that imply literal contact with living organisms.

The expressive degree of purity of the $\alpha$ plaster sample analyzed in this work was superior when compared to the degrees of purity of samples of calcium sulfate hemihydrates, also $\alpha$ type, from other countries.

The combination of the results of the structural and chemical characterizations (XRD, XRF, TGA and FT-IR) converged to a uniqueness, endorsing each other, with regard to the presence of contaminating components in concentrations that do not disprove the indication of 
$\alpha$ plaster, analyzed in this work, for applications considered more noble and distinct from the classic and trivial applications for civil construction.

The morphological analysis, carried out by the SEM technique, revealed that the unitary constituent particles of the $\alpha$ plaster sample, as well as their agglomerates, presented with elongated and thin shapes with average sizes, approximately uniform, around $60 \mu \mathrm{m}$. The morphology presented by the particles presented to be suitable for applications that require the manufacture of parts with appreciable mechanical resistance, thanks to their physical predisposition to form residual shear stresses.

\section{Acknowledgements}

The authors are grateful for the financial support of CNPq and the Federal University of Cariri, which made possible the development of this research. We would also like to thank the company of the Plasterer Polo of Araripe that provided the $\alpha$ plaster sample analyzed in this research.

\section{References}

Abreu E.M.X. (2005) Estudo da influência de diferentes gessos produzidos na região nordeste do Brasil para a fabricação de moldes utilizados na indústria de louças sanitárias. Dissertação (Programa de Pós-Graduação em Engenharia Mecânica). Universidade Federal de Pernambuco, Recife, Pernambuco.

Baltar C.A.M., Bastos F.F. \& Luz A.B. (2008) Rochas e Minerais industriais: Gipsita. $2^{\circ}$ edição. Rio de Janeiro: CETEM-MCT. 505 p.

Barbosa A.A., Ferraz A.V. \& Santos G.A. (2014) Caracterização química, mecânica e morfológica do gesso obtido do polo do Araripe. Cerâmica, 60: 501-508. https://doi.org/10.1590/S036669132014000400007

Buggakupta W., Tounchuen K., Panpa W. \& Jinawath S. (2020) Early Production of High Strength and Improved Water Resistance Gypsum Mortars from Used Plaster Mould and Cullet Waste. Journal of Materials in Civil Engineering, 32: 1-9. https://doi.org/10.1061/(ASCE)MT.1943-5533.0003179

Canut M.M.C. (2006) Estudo da viabilidade do uso do resíduo fosfogesso como material de construção. Dissertação (Programa de Pós-Graduação em Construção Civil). Universidade Federal de Minas Gerais, Belo Horizonte, Minas Gerais.

Chang H., Xiang H., Yao Z., Yang S., Tu M., Zhang X. \& Yu B. (2020) Strontium-substituted calcium sulfate hemihydrate/hydroxyapatite scaffold enhances bone regeneration by recruiting bone mesenchymal stromal cells. Journal of Biomaterials Applications, 35: 97-107. https://doi.org/10.1177/0885328220915816

Chen Y., Tan Y., Hu K. \& Tan W. (2020) Role of Continuous Nursing in Consolidating the Therapeutic Effect and Promoting the Rehabilitation of Patients with Clubfoot. Investigación Clínica, 61: 1502-1508.

Costa J.E.B. (2013) Análise comparativa entre as propriedades do gesso obtido da produção de sal e gessos comerciais. Dissertação (Programa de Pós-Graduação em Engenharia e Ciência de Materiais). Universidade Federal do Rio Grande do Norte, Natal, Rio Grande do Norte.

Engbrecht D.C. \& Hirschfeld D.A. (2016) Thermal analysis of calcium sulfate dihydrate sources used to manufacture gypsum wallboard. Thermochimica Acta, 639: 173-185.

https://doi.org/10.1016/j.tca.2016.07.021

Ferreira F.C., Sousa J.G.G. \& Carneiro A.M.P. (2019) Caracterização mecânica do gesso para revestimento produzido no Polo Gesseiro do Araripe. Revista Ambiente construído, 19: 207 221. https://doi.org/10.1590/s1678-86212019000400352

Guan W., Qi Q., Zhang Z. \& Nan S. (2020) Effect of Sand Particle Size on Microstructure and Mechanical Properties of Gypsum-Cemented Similar Materials. Materials, 13: 1-16. https://doi.org/10.3390/ma13030765 
Gurgul S.J., Seng G. \& Williams G.R. (2019) A kinetic and mechanistic study into the transformation of calcium sulfate hemihydrate to dihydrate. Journal of Synchrotron Radiation, 26: 774-784. https://doi.org/10.1107/S1600577519001929

Huynh M.D., Trung T.H., Dat N.H. \& Giang N.V. (2020) The melting rheology, mechanical properties, thermal stability and morphology of polylactic acid/ethylene bis stearamide modified gypsum composite. Vietnam Journal of Chemistry, 58: 251-255. https://doi.org/10.1002/vjch.201900187

Krause F., Renner B., Coppens F., Dewanckele J. \& Schwotzer M. (2020) Reactivity of GypsumBased Materials Subjected to Thermal Load: Investigation of Reaction Mechanisms. Materials, 13: 2-15. https://doi.org/10.3390/ma13061427

Kwon K., Kim M. \& Shin B. (2016) Making Dentition Model from Negative Dental Impression in Implant Treatment. International Journal of Morphology, 34: 1404-1410. https://doi.org/10.4067/S0717-95022016000400037

Li X. \& Zhang Q. (2020) Effect of Molecular Structure of Organic Acids on the Crystal Habit of $\alpha$-CaSO ${ }_{4} \cdot 0.5 \mathrm{H}_{2} \mathrm{O}$ from Phosphogypsum. Crystals, 10: 2-15. https://doi.org/10.3390/cryst10010024

Lira M.C.A., Lima P.H.P., Brasileiro M.I. \& Neiva L.S. (2018) Estudo comparativo das características e propriedades dos diferentes tipos de gipsita exploradas no polo gesseiro do Araripe: uma revisão. $X X$ Congresso de Estudantes de Ciência e Engenharia de Materiais do MERCOSUL, 20: 59-68.

Maale G.E., Eager J.J., Mohammadi D.K. \& Calderon II F.A. (2020) Elution Profiles of Synthetic $\mathrm{CaSO}_{4}$ Hemihydrate Beads Loaded with Vancomycin and Tobramycin. European Journal of Drug Metabolism and Pharmacokinetics, 45: 1-9. https://doi.org/10.1007/s13318-020-00622-8

Marandi M., Jahani D., Uromeihy A. \& Reihan M.K. (2017) Analysis of Structure and Textures of Anhydrite Mineral in Gachsaran Formation in Gotvand Area, Iran. Open Journal of Geology, 7: 1478-1493. https://doi.org/10.4236/ojg.2017.710099

Marvila M.T., Azevedo A.R.G., Barroso L.S., Barbosa M.Z. \& Brito J. (2020) Gypsum plaster using rock waste: A proposal to repair the renderings of historical buildings in Brazil. Construction and Building Materials, 250: 12-21. https://doi.org/10.1016/j.conbuildmat.2020.118786

Ngoc Le N.T., Trang Le N.T., Nguyen Q.L., Pham T.L.-B., Nguyen-Le M.-T. \& Nguyen D.H. (2020) A Facile Synthesis Process and Evaluations of $\alpha$-Calcium Sulfate Hemihydrate for Bone Substitute. Materials, 13: 2-13. http://https://doi.org/10.3390/ma13143099

Oliveira J.M.S. \& Torres S.M. (2015) Efeito da cominuição dos grãos de gesso antes da hidratação na microestrutura dos produtos hidratados. Revista Principia - Divulgação Científica e Tecnológica do IFPB, 1: 64-71. http://dx.doi.org/10.18265/1517-03062015v1n26p64-71

Ritterbach L. \& Becker P. (2020) Temperature and humidity dependent formation of CaSO4.xH2O (x = 0...2) phases. Global and Planetary Change, 187: 103132. https://doi.org/10.1016/j.gloplacha.2020.103132

Rosen E.B., Ahmed Z.U., Huryn J.M. \& Ganly I. (2019) Prosthetic rehabilitation of the geriatric oncologic rhinectomy patient utilizing a craniofacial implant-retained nasal prosthesis. Clinical case reports, 8: 278-282. https://doi.org/10.1002/ccr3.2629

Shahrajabian M.H., Sun W., Shen H. \& Cheng Q. (2020) Chinese herbal medicine for SARS and SARS-CoV-2 treatment and prevention, encouraging using herbal medicine for COVID-19 outbreak. Acta Agriculturae Scandinavica, Section B - Soil \& Plant Science, 70: 437-443. https://doi.org/10.1080/09064710.2020.1763448

Soares J.P., Leite L.R.P., Shinohara A.H., Sugiyama K. \& Suzuki C.K. (2005) Caracterização dos gessos- $\alpha$ produzidos por processo hidrotermal e calcinação sob pressão de vapor de água pela técnica de difração de Raios-X de alta resolução. Anais do $49^{\circ}$ Congresso Brasileiro de Cerâmica, 4: 44-52.

Wang Y-X., Ma J-R., Wang S-Q., Zeng Y-Q., Zhou C-Y., Ru Y-H., Zhang L., Lu Z-G., Wu M-H. \& Hui Li. (2020) Utilizing integrating network pharmacological approaches to investigate the potential mechanism of Ma Xing Shi Gan Decoction in treating COVID-19. European Review for Medical and Pharmacological Sciences, 24: 3360-3384. 
https://doi.org/10.26355/eurrev_202003_20704

Zhang Y., Tao W., Wang K. \& Li D. (2020) Analysis of thermal properties of gypsum materials incorporated with microencapsulated phase change materials based on silica. Renewable Energy, 149: 400-408. https://doi.org/10.1016/j.renene.2019.12.051

Zhao X., Kuang S., Su C., Xiao W., Lei G. \& Ga S. (2020) Arthroscopic Treatment of Femoral Avulsion Fracture of the Posterior Cruciate Ligament in Association with Meniscus Tear. Orthopaedic surgery, 12: 692-697. https://doi.org/10.1111/os.12636

Zhou Z., Zhu C. \& Zhang B. (2020) Study on medication regularity of traditional Chinese medicine in treatment of COVID-19 based on data mining. China Journal of Chinese Materia Medica, 45: 1248-1252. https://doi.org/10.19540/j.cnki.cjcmm.20200220.502 